Vol. 3, No. 1, 2021

https://doi.org/10.23939/jtbp2021.01.120

Orest Voznyak, Yurij Yurkevych, Oleksandr Dovbush, Khrystyna Myroniuk, Iryna Sukholova

\title{
GRAPHIC-ANALYTICAL METHOD OF CONSTRUCTION OF PATTERNS OF VENTILATION FITTINGS
}

\author{
Lviv Polytechnic National University, \\ Department of Heat and Gas Supply and Ventilation \\ orest.voznyak@i.ua
}

(C) Voznyak O., Yurkevych Yu., Dovbush O., Myroniuk Kh., and Sukholova I., 2021

The article presents the results of theoretical and experimental developments regarding the marking of scans and patterns of fittings of the ventilation system, provided that the unification of installation and procurement work. The aim of the work is to create a graph-analytical method to unify the construction of patterns of ventilation fittings, in particular in the design and manufacture of adapters of different shapes and sizes; increasing the efficiency of procurement work for installation of ventilation systems in production facilities by minimizing material waste during their manufacture, and reducing the material consumption of products. The application of the proposed graphicanalytical method will increase the efficiency of procurement and installation work and thus reduce the amount of waste and material consumption for the manufacture of ventilation fittings for various purposes.

Key words: installation, procurement work, ventilation, pattern, fitting, adapter.

\section{Introduction}

The indoor microclimate is maintained by a ventilation system (Gumen et al., 2016; Voznyak et al., 2005). The main conditions of comfort are the provision of normalized air velocity and indoor temperature (Dovhaliuk \& Mileikovskyi, 2007; Voznyak et al., 2005). This task is solved by the proper organization of air exchange and the scheme of air distribution in the room (Dovhaliuk \& Mileikovskyi, 2008; Voznyak et al., 2019). Maintaining a comfortable climate meets human physiological needs and affects health and performance (Dovhaliuk \& Mileikovskyi, 2013; Voznyak et al., 2005). Along with these air parameters, the concentration of CO2 in the room is of great importance (Kapalo et al., 2019; Kapalo et al., 2018, Kapalo et al., 2014).

To solve this complex problem, there is a need to increase the efficiency of installation and procurement of ventilation systems (Zhelykh, et al., 2019). In particular, there is a need to create a graphanalytical method to unify the construction of templates for ventilation fittings for different purposes, shapes and sizes. This will increase the efficiency of procurement work for the installation of ventilation systems in production facilities by minimizing material waste during their manufacture, and reducing the material consumption of products.

\section{Target of this article}

The aim of this work is to create a graph-analytical method to unify the construction of templates for ventilation fittings, in particular in the design and manufacture of adapters of different shapes, sizes and purposes; increasing the efficiency of procurement work for the installation of ventilation systems in 
production facilities by minimizing material waste during their manufacture, and reducing the material consumption of products.

\section{Techniques used}

In ventilation technology, metal air ducts of round, square and rectangular cross-section are usually used (Zhelykh, et al., 2019; Dovhaliuk \& Mileikovskyi, 2007; Dovhaliuk \& Mileikovskyi, 2008). adapters with flanges (Dovhaliuk \& Mileikovskyi, 2013; Gumen et al., 2016) Similarly, devices for distributing indoor air are connected to air ducts (Voznyak et al., 2005; Voznyak et al., 2019). air distributors do not match the shape and size of the air ducts to which they are connected.Therefore, there is a need for maximum unification in the manufacture of templates for these fittings, For this purpose a graphanalytical method of constructing fitting templates is created.

\section{Marking a straight change-over from a larger diameter to a smaller one}

The initial values for the construction are the values of both diameters $D$ and $d$, as well as the length of the transition $l$. The required values are the angle $\alpha$ and the radii $R l$ and $R 2$.

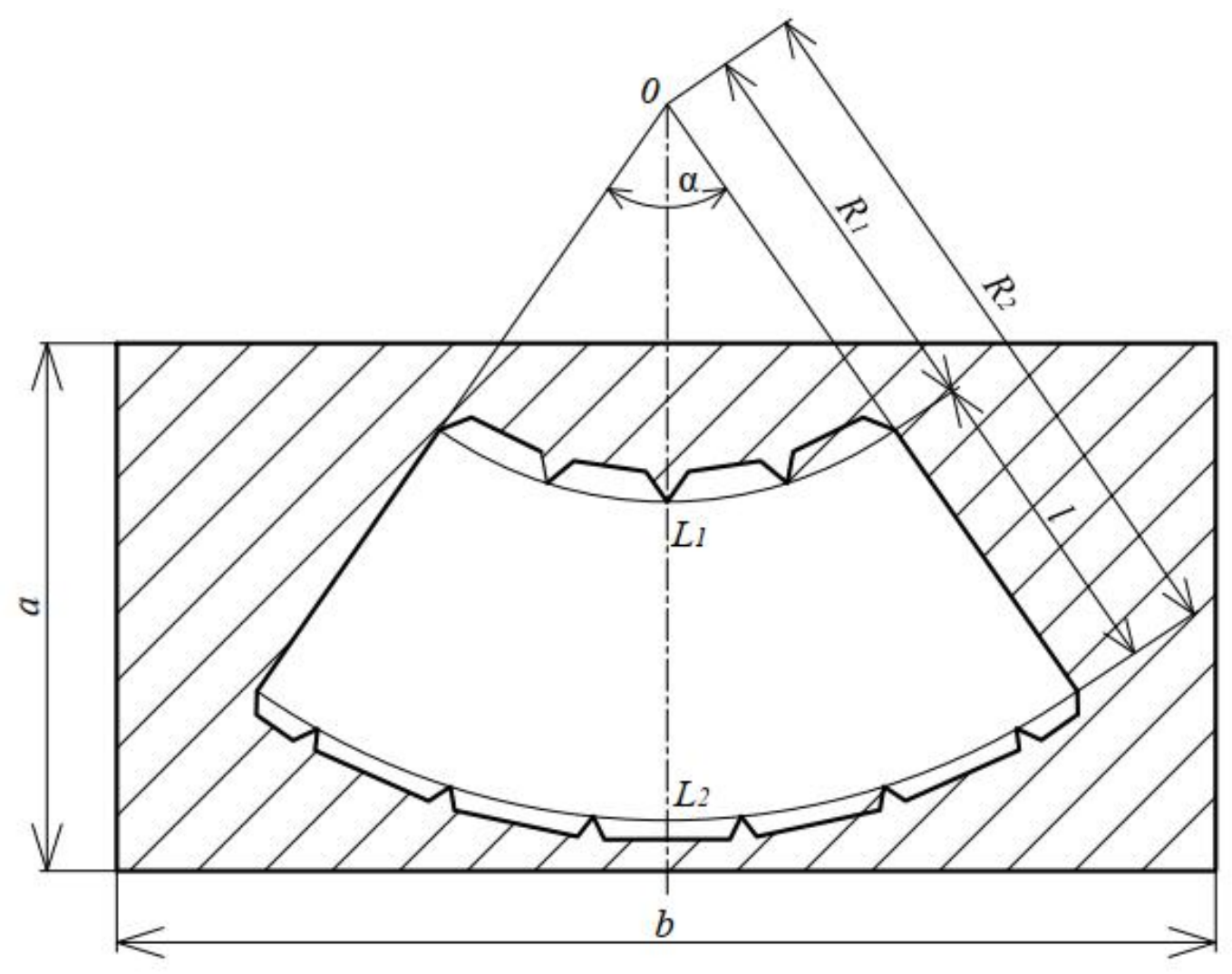

Fig. 1. The scheme of construction of the scan (template) of the change-over from diameter $D$ to diameter $d$ (where $a \times b$-the size of a standard metal sheet)

In Fig. $1 L 1$ and $L 2$ are the arcs of a circle with center in point $O$ which are drawn by the corresponding radii:

$$
\begin{gathered}
R_{1}=l \cdot \frac{d}{D-d} ; \\
R_{2}=R_{1}+l=l \cdot \frac{D}{D-d} ;
\end{gathered}
$$


with central angle $\alpha$ :

$$
\alpha=\frac{180 \cdot(D-d)}{l}
$$

\section{Marking the change-over from round to rectangular}

Initial data: the dimensions of the rectangular end $A \times B$, the diameter of the round end $D$, the length of the transition $l$. The required values are the angle $\alpha$ and the radii $R 1$ and $R 2$.

The perimeter of the rectangular end is smaller than the perimeter of the round end.

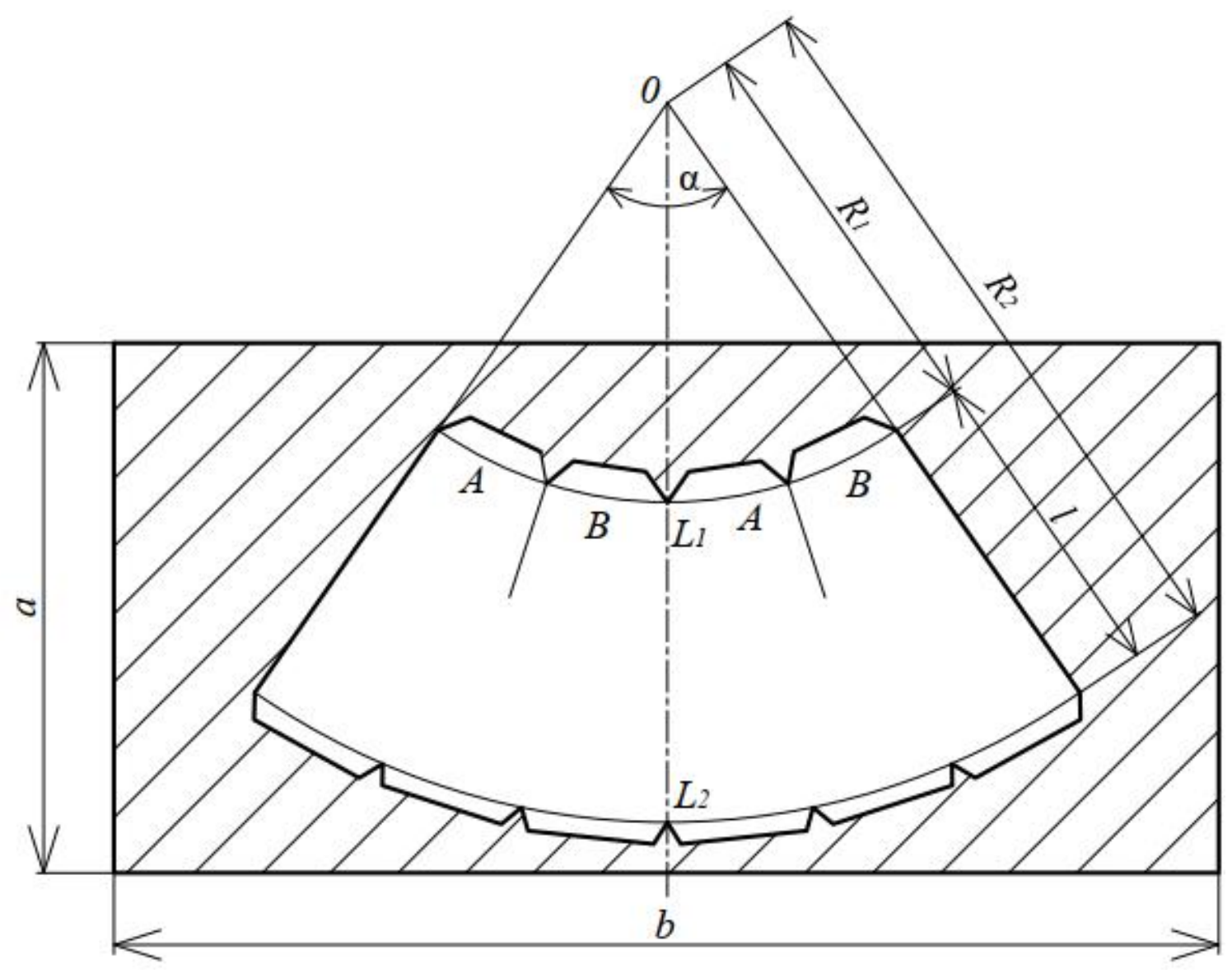

Fig. 2. The scheme of construction of the scan (template)

of the change-over from a round cross section to a rectangular smaller perimeter

The analytical dependences are accordingly as follows:

$$
\begin{gathered}
R_{1}=\frac{2 \cdot(A+B) \cdot l}{\pi D-2 \cdot(A+B)} ; \\
R_{2}=R_{1}+l=\frac{\pi D \cdot l}{\pi D-2 \cdot(A+B)} ; \\
\alpha=\frac{180 \cdot(\pi D-2 \cdot(A+B))}{\pi l} .
\end{gathered}
$$


The perimeter of the rectangular end is larger than the perimeter of the round end.

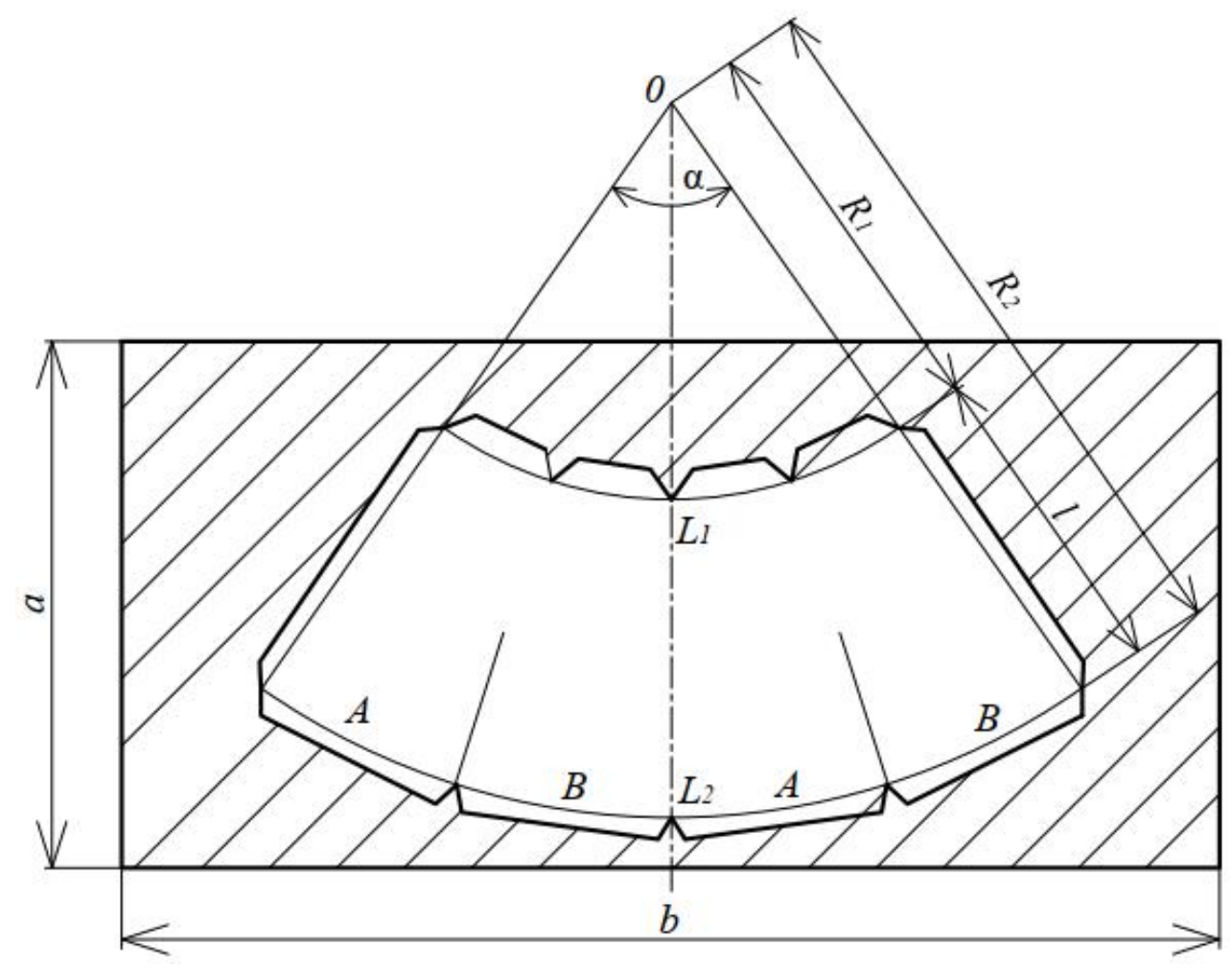

Fig. 3. The scheme of construction of the scan (template)

of the change-over from a round section

to a rectangular larger perimeter

Similar analytical dependences:

$$
\begin{gathered}
R_{1}=\frac{\pi D \cdot l}{2(A+B)-\pi D} \\
R_{2}=R_{1}+l=\frac{2(A+B) \cdot l}{2(A+B)-\pi D} \\
\alpha=\frac{180 \cdot(2(A+B)-\pi D)}{\pi l} .
\end{gathered}
$$

\section{Marking the adapter from square to rectangular}

It should be noted that only the case of a larger perimeter of a rectangular end is possible, since it is known that a square has the maximum area of rectangles of the same perimeter. Suppose we have a square with side $a$ on one end of the adapter and a rectangle of size $b \times c$ on the other end. The template is four alternately connected faces in the form of trapezoids of the following sizes: bases with length $a$ and $b$ and height $h$ (face $A B C D$ ) and bases with length $a$ and $c$ and height $h$ (face $C D E F$ ) (Fig. 4). The appropriate height $h$ must satisfy the requirement of a smooth transition and the inadmissibility of a sudden narrowing as a local resistance. The angles of inclination $\alpha$ and $\beta$ depend on the sizes $a, b, h$ and $a, c, h$, respectively, and are defined as $\operatorname{tg} \alpha$ and $\operatorname{tg} \beta$ from formulas $(10,11)$, respectively:

$$
\operatorname{tg} \alpha=\frac{b-a}{2 h} ;
$$




$$
\operatorname{tg} \beta=\frac{a-c}{2 h} .
$$

After placing the face $A B C D$ on the template, it is necessary to attach the face CDEF at an angle $\gamma$, which is defined as $\gamma=\alpha-\beta$. Similarly, at the same angle $\gamma$ alternately join the faces $E F G H$ and $G H K L$.
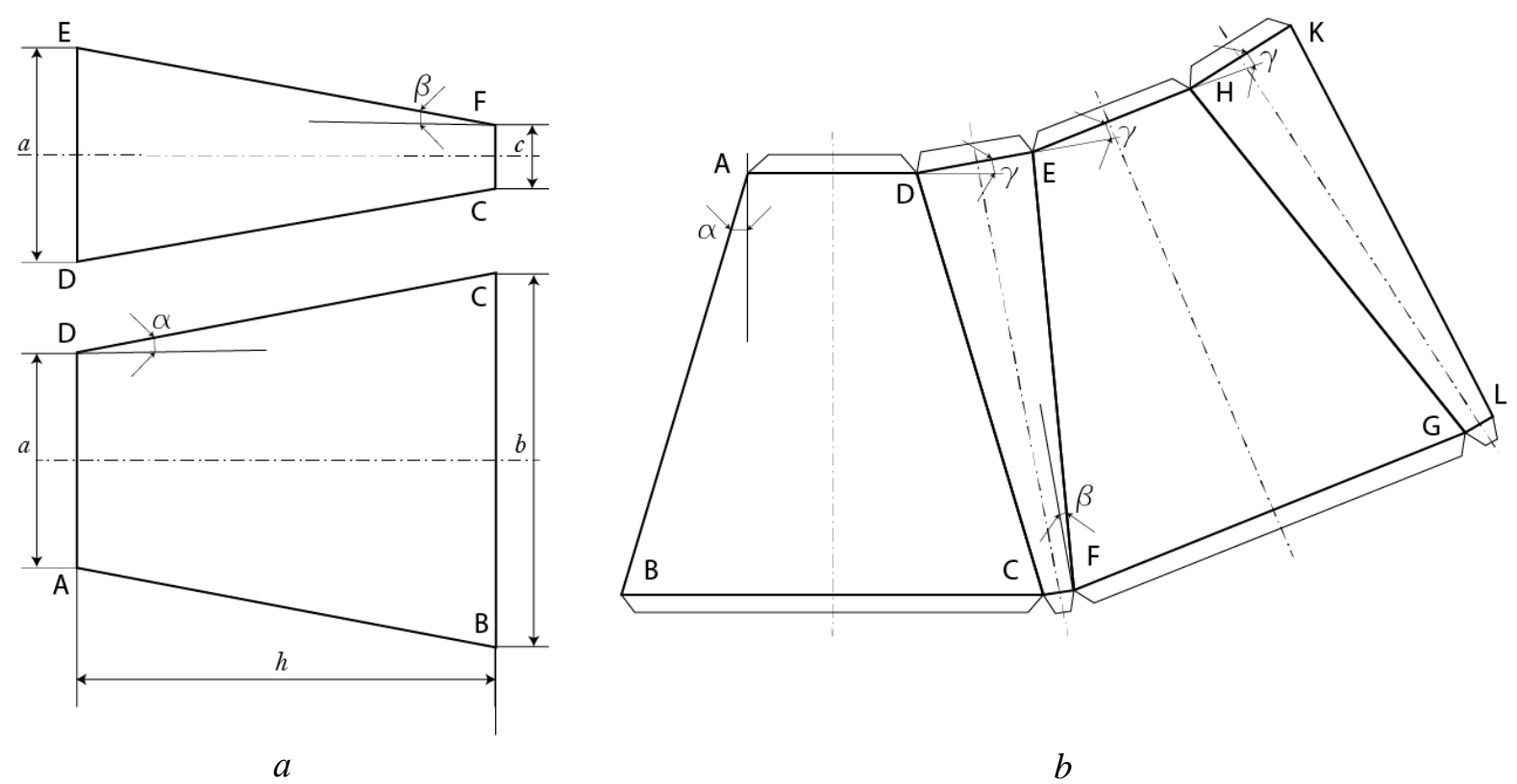

Fig. 4. The scheme of construction of the adapter template from a square section on a rectangle of larger perimeter: $a$-drawings in projection connection; $b$-template

Because $\gamma=\alpha-\beta$, then taking into account (10) and (11), we obtain:

$$
\gamma=\operatorname{arctg} \frac{b-a}{2 h}-\operatorname{arctg} \frac{a-c}{2 h} \text {. }
$$

According to the geometric construction of the $A B$ face of $A B C D$ is determined from formula (13):

$$
A B=0.5 \sqrt{4(b-a)^{2}+h^{2}+4(a-c)^{2}},
$$

where $a, b, c, h$ - linear dimensions (Fig. 4).
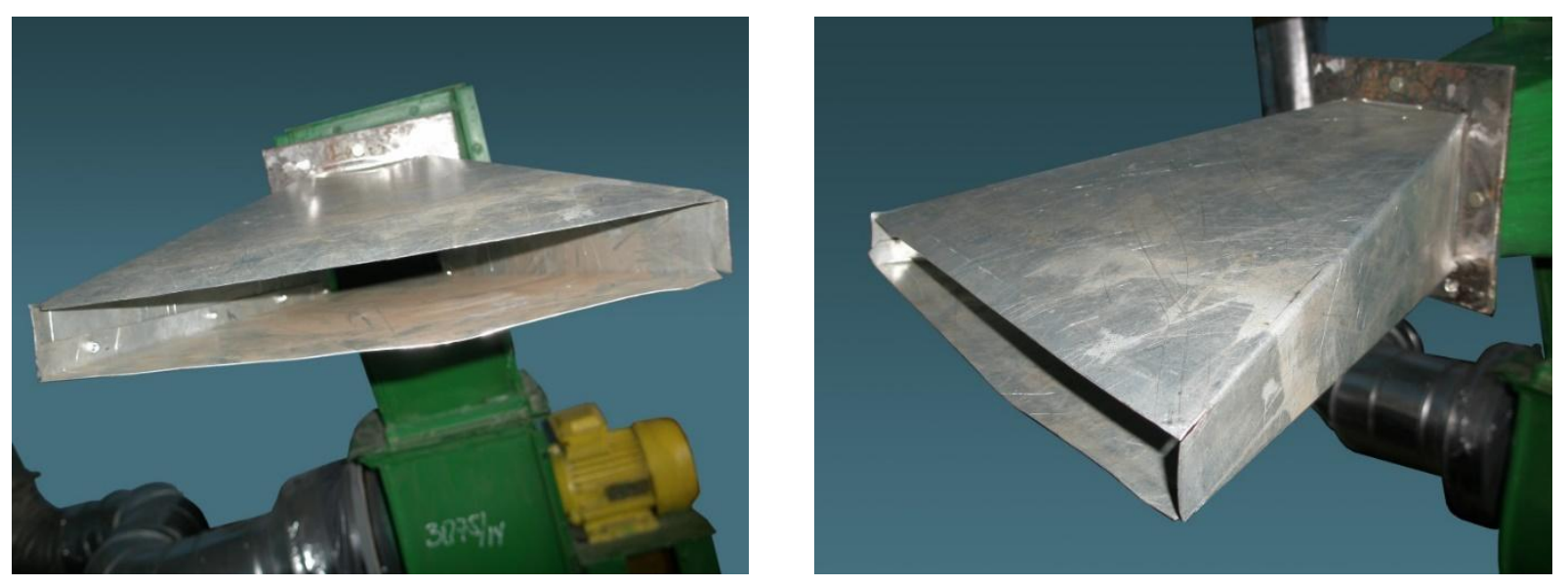

Fig. 5. Full-scale experimental samples of adapters from the end of $10 \times 10 \mathrm{~cm}$ at the end of adapter $3 \times 30 \mathrm{~cm}$ 

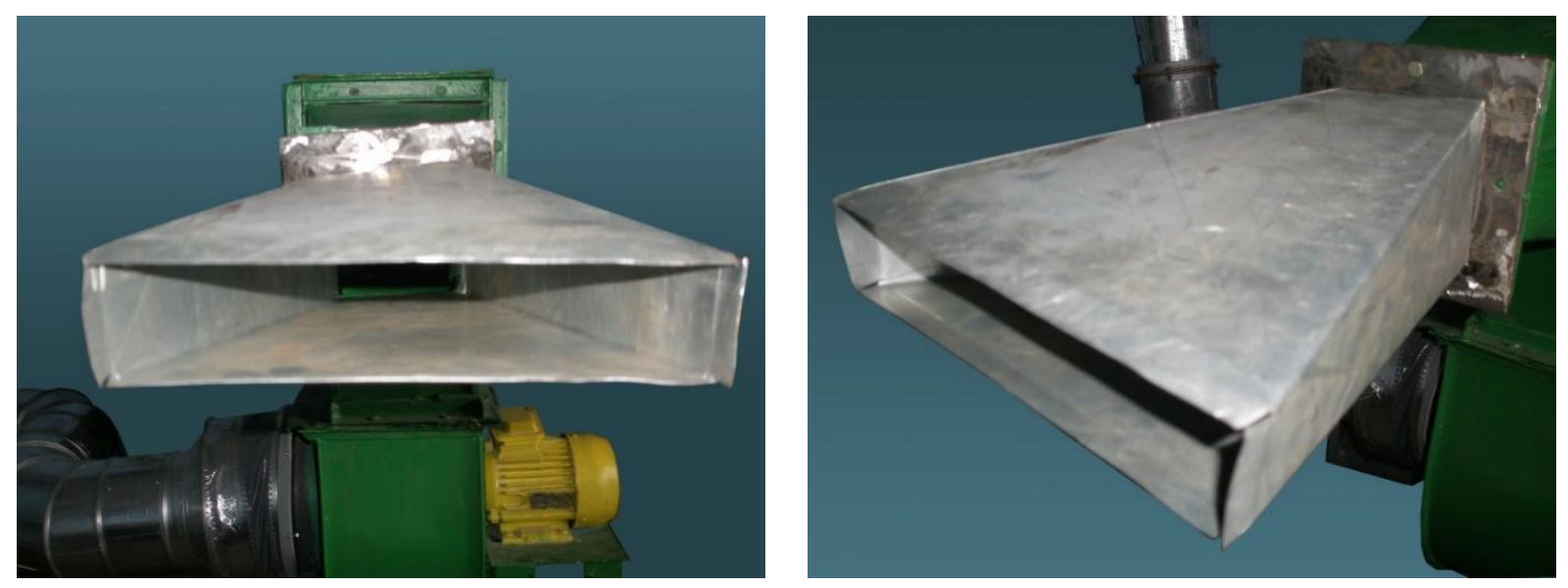

Fig. 6. Full-scale experimental samples of adapters from the end of $10 \times 10 \mathrm{~cm}$ at the end of adapter $4.5 \times 22.5 \mathrm{~cm}$
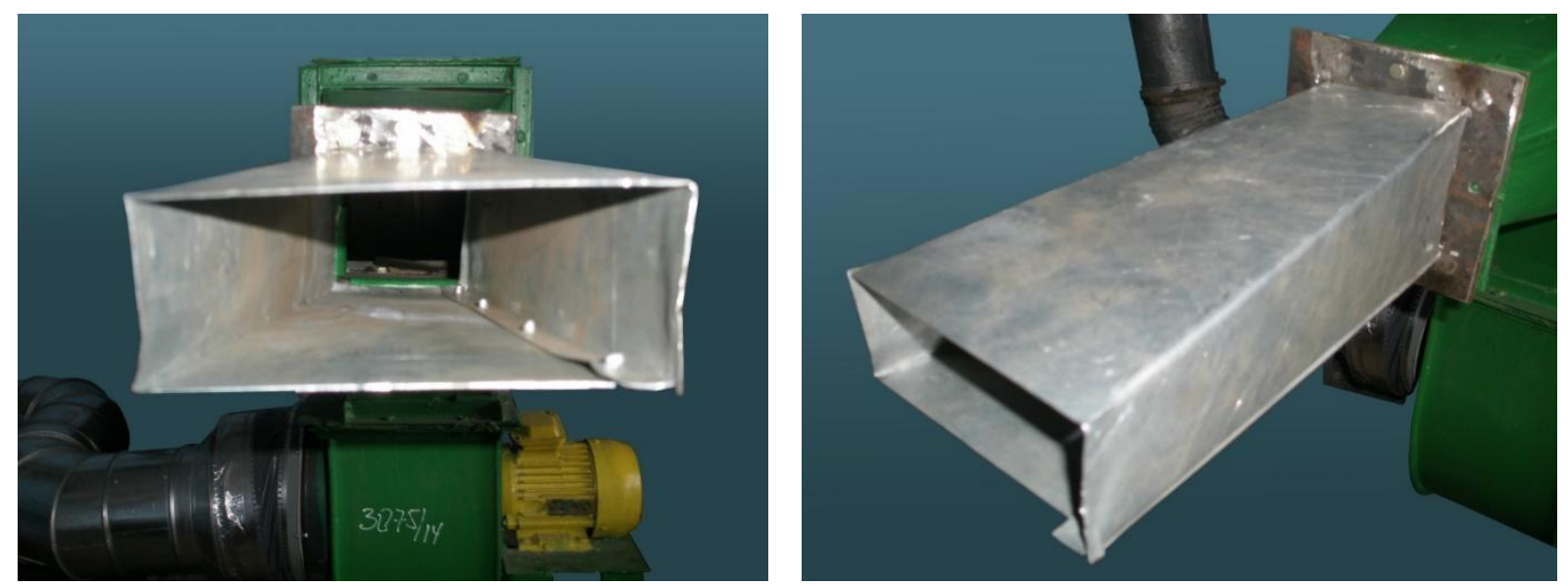

Fig. 7. Full-scale experimental samples of adapters from the end of $10 \times 10 \mathrm{~cm}$ at the end of adapter $6 \times 15 \mathrm{~cm}$

Figures 5, 6 and 7 present full-scale experimental samples of different sizes, which are made according to a template built using the developed graph-analytical method (Fig. 4).

\section{Conclusions}

1. The calculated dependences for construction of templates of adapters of various form and the sizes, and also exhaust hoods of various diameters and height are received

2. Technological maps for execution of templates of fittings of ventilation system are developed.

3. The application of the proposed graph-analytical method will increase the efficiency of procurement and installation work and thus reduce the amount of waste and material consumption for the manufacture of ventilation fittings for various purposes.

4. Made full-scale experimental samples of different sizes on templates, built using the developed graph-analytical method, confirm its reliability.

\section{References}

Kapalo, P., Domnita, F., Bacotiu, C., \& Spodyniuk, N. (2018). The impact of carbon dioxide concentration on the human health - case study, Journal of Applied Engineering Sciences, Vol. 8, No. 1, 61-66. ISSN 2284-7197, DOI: $10.15587 / 1729-4061.2016 .74868$. 
Kapalo, P., Meciarova, L., Vilcekova, S., Burdova, E., Domnita, F., Bacotiu, \& C. Peterfi, K. (2019). Investigation of $\mathrm{CO}_{2}$ production depending on physical activity of students. International Journal of Environmental Health Research. Vol. 29, Issue 1. 31-44. ISSN:09603123. DOI: 10.1080/09603123.2018.1506570.

Kapalo, P., Voznyak, O., Yurkevych, Yu., Myroniuk, Kh., \& Sukholova, I. (2018). Ensuring comfort microclimate in the classrooms under condition of the required air exchange, Eastern European Journal of Enterprise Technologies, Vol 5/10 (95). 6-14. DOI: 10.15587/1729-4061.2018.143945.

Voznyak, O., Korbut, V., Davydenko, B., \& Sukholova, I. (2019). Air distribution efficiency in a room by a two-flow device. Proceedings of CEE, Advances in Resourse-saving Technologies and Materials in Civil and Environmental Engineering, Springer, Vol 47. 526-533. DOI: 10.1007/978-3-030-27011-7_67.

Gumen, O. M., Dovhaliuk, V. B., \& Mileikovskyi, V. O. (2016). Determination of the intensity of turbulence of streams with large-scale vortices on the basis of geometric and kinematic analysis of macrostructure. Proc. of Lviv Polytechnic National University: The theory and building practice, No.844. 76-83 (in Ukrainian).

Dovhaliuk, V. B., \& Mileikovskyi, V .O. (2007). Efficiency of organization of air exchange in heat-stressed premises in compressed conditions, Journal: Building of Ukraine, No. 3, 36 (in Ukrainian).

Dovhaliuk, V. B., \& Mileikovskyi, V. O. (2008). Estimated model of non-isothermal stream, which is laid out on a convex cylindrical surface. Ventilation, Illumination and Heat and Gas Supply: Scientific and Technical Collection, Issue 12, Kyiv, KNUBA, 11-32 (in Ukrainian).

Dovhaliuk, V. B., \& Mileikovskyi, V. O. (2013). Analytical studies of the macrostructure of jet currents for calculating energy-efficient systems of air distribution. Energy efficiency in construction and architecture, Issue 4, $11-32$ (in Ukrainian).

Zhelykh, V. M., Voznyak, O. T., Dovbush, O. M., Yurkevich, Yu. S., \& Savchenko, O. O. (2019). Technologies of procurement and installation of heating and ventilation systems. Lviv: Lviv Polytechnic Publishing House (in Ukrainian).

Hnativ, R., \& Verbovskiy. O. (2019). Distribution of local velocities in a circular pipe with accelerating fluid flow. Eastern-European Journal of Enterprise Technologies, 2 (7-98): 58-63. DOI: 10.15587/1729-4061.2019.162330.

Hulai, B., Dovbush, O., Piznak, B., \& Kasynets, M. (2020). Studying Equalization of the Radial Fans Discharge Flow. Lecture Notes in Civil Engineering, 47. 119-126. DOI: 10.1007/978-3-030-27011-7_15.

Janbakhsh, S., \& Moshfegh, B. (2014). Experimental investigation of a ventilation system based on wall confluent jets. Building and Environment, 80. 18-31. DOI: 10.1016/j.buildenv.2014.05.011.

Korbut, V., Voznyak, O., Myroniuk, Kh., Sukholova, I., \& Kapalo, P. (2017). Examining a device for air distribution by the interaction of counter non-coaxial jets under alternating mode. Eastern European Journal of Enterprise Technologies, 8(86). 30-38. DOI: 10.15587/1729-4061.2017.96774.

Spodyniuk, N., Gulai, B., Zhelykh, V., \& Shapoval, S. (2019). Leveling of pressure flow of radial ventilator in mine ventilation system. Naukovyi Visnyk Natsionalnoho Hirnychoho Universytetu, 6. 80-86. DOI: $10.29202 /$ nvngu/2019-6/12.

Lorin E. (2019). From structured data to evolution linear partial differential equations. Journal of Computational Physics, 393, 162-185. DOI: 10.1016/j.jcp.2019.04.049.

\section{О. Т. Возняк, Ю. С. Юркевич, О. М. Довбуш, Х. В. Миронюк, І. Є. Сухолова}

Національний університет “Львівська політехніка",

кафедра теплогазопостачання і вентиляції

\section{ГРАФО-АНАЛІТИЧНИЙ МЕТОД ПОБУДОВИ ШАБЛОНІВ ВЕНТИЛЯЦІЙНИХ ФІТИНГІВ}

(С Возняк О. Т., Юркевич Ю. С., Довбуш О. М., Миронюк Х. В., Сухолова I. С., 2021

Наведено результати теоретичних та експериментальних розробок стосовно розмічання розгорток та шаблонів фітингів системи вентиляції за умови забезпечення уніфікації монтажно-заготівельних робіт. Отримано картини перехідників з повітропроводів квадратного поперечного перерізу на прямокутні різних розмірів та співвідношення сторін, а також на повітропроводи круглого поперечного перерізу. Створено графо-аналітичний метод побудови шаблонів вентиляційних фітингів 
різного призначення. Виготовлено натурні експериментальні взірці різних розмірів, які виготовлено за шаблоном, побудованим за допомогою розробленого графо-аналітичного методу. Метою роботи $\epsilon$ створення графо-аналітичного методу для уніфікації побудови шаблонів вентиляційних фітингів, зокрема під час проектування та виготовлення перехідників різних форм та розмірів; підвищення ефективності заготівельних робіт для монтажу вентиляційних систем у виробничих приміщеннях за рахунок мінімізації відходів матеріалу під час їх виготовлення, та зниження матеріалоємності продукції. Отримано розрахункові залежності для побудови шаблонів перехідників різної форми та розмірів, а також розроблено технологічні карти для виконання шаблонів фітингів системи вентиляції. Застосування запропонованого графо-аналітичного методу забезпечить підвищення ефективності заготівельно-монтажних робіт і тим самим зменшить кількість відходів та витрату матеріалів на виготовлення вентиляційних фітингів різного призначення.

Наведено уніфіковану схему побудови шаблона перехідника 3 квадратного перерізу меншого периметра на прямокутні перерізи більшого периметра різних розмірів у вигляді креслення в проекційному зв'язку та універсального шаблона.

Ключові слова: монтаж, заготівельні роботи, вентиляція, шаблон, фітинг, перехідник. 